\title{
Grazing behavior of the greek breed of sheep "Serres" in lowland and mountainous pastures
}

\begin{abstract}
Athanasios Loridas', loannis Mountousis², Christos Roukos', Maria Yiakoulaki ${ }^{3}$ and Kostantinos Papanikolaou'

'Department of Animal Production, Faculty of Agriculture, Aristotle University of Thessaloniki, Thessaloniki, Greece, ${ }^{2}$ Department of Animal Production, Faculty of Agriculture, Technological Educational Institute of Western Macedonia, Terma Kontopoulou, Florina, Greece, ${ }^{3}$ Department of Range and Wildlife Science (236), School of Forestry and Natural Environment, Aristotle University of Thessaloniki, Thessaloniki, Greece
\end{abstract}

\begin{abstract}
The grazing activities of indigenous sheep of the greek breed "Serres" was investigated in a typical lowland, and in a mountainous pasture in northern Greece during the vegetative period (April-October) of 2008. Grazing time, resting and ruminating time, distance travel and air temperature in relation to pasturing month and altitude were examined. It was remarked significant effect $(P<0.001)$ of the pasturing month on grazing time, and resting time of sheep. Mean grazing time was greater in the lowland (315.71 min/day \pm 4.57$)$ than in the mountainous pasture $(283.57 \mathrm{~min} / \mathrm{day} \pm 4.79)$. On the contrary, the resting time and the distance travel of sheep were shorter in the lowland pasture. The resting time had significant $(P<0.01)$ positive relationship to air temperature $(r=0.777)$.
\end{abstract}

Keywords: grazing activity, vegetative period, sheep breed "Serres", lowland pasture, mountainous pasture, northern Greece

\section{Zusammenfassung}

\section{Weideverhalten der griechischen Schafrasse "Serres" auf Tiefland- und Bergweide in Nordgriechenland}

Im Jahr 2008 erfolgten in den Monaten April bis Oktober Beobachtungen des Weideverhalten von Schafen unter den Bedingungen des Tieflandes als auch im Gebirge Nordgriechenlands. Bei den Herden der einheimischen Schafrasse "Serres" wurden die Weideaktivitäten Fresszeit, Ruhezeit, Wegstrecke, und Zeit des Wiederkauens je Tag erfasst und hinsichtlich Weidemonat und Untersuchungsstandort ausgewertet. Signifikante Beziehungen ergaben sich bei allen Merkmalen zum Weidemonat. Die mittleren Weidezeiten im Tiefland betrugen 315,7 $\pm 4,6$ Min/Tag bei der Gebirgsweide 283,6 $\pm 4,8$ Min/Tag. Im Gegensatz zu dieser Beobachtung waren die Wegstrecken und die Ruhezeiten in der Tieflandweide kürzer. Für die Ruhezeiten ergaben sich mit $\mathrm{r}=+0,777$ signifikante Beziehungen zur Lufttemperatur.

Schlüsselwörter: Weideverhalten, Vegetationsperiode, Schafrasse Serres, Tieflandweide, Bergweide, Nordgriechenland 


\section{Introduction}

Pastures are complex ecosystems upon which livestock production depends. One common element, however, is that they comprise a wide range of species (Kemp et al. 2003). Lowland pastures are located in plain and hilly areas; they are grazed during winter or the major part of the year (Sarlis 1998). They are dominated by annual plants, and they characterized by the high amount of legumes and forbs. Mountainous pastures, which located up to $600 \mathrm{~m}$, are characterized by a rough topography and great variability of plant communities and herbage cover (Aldezabal et al. 1999). Their flora composed mainly by perennial grasses and glass-like plants as well as of some forbs and shrubs. They are grazed seasonally, from mid- spring to autumn, while they are covered by snow during winter (Sarlis 1998). However, in recent years changes in land use in Europe has caused a reduction in lowland pastures biodiversity, whereas many traditionally managed mountain pastures are still species- rich (Spiegelberger et al. 2006).

Grazed pastures represent a specific, but synthetic ecological system with crucial dependent variables such as nutrition and environmental controls influencing the dominant plant and animal species (Squires 1975). In recent years, it has been increasingly realized that grazing of sheep considerably contributes to a sustainable management of agricultural areas and to landscape preservation (Brüne \& Stumpf 2004, Seibert et al. 2004, Fischer et al. 2007).

Sheep production constitutes a major agricultural activity in the Mediterranean basin and plays an important role from an economic, cultural, ecological and environmental point of view (Zervas et al. 1996). The existing sheep production systems in Greece (Yiakoulaki et al. 2003) are based on traditional grazing of communal natural grasslands, which can provide herbage to animals only for 6-7 months during the year (spring-autumn in the lowland and summer in the highland).

Apart from performance characteristics and ethological specifics, the origin of the animal populations concerned, i.e. natural site conditions at their places of origin including such factors as climate, soil characteristics, and fodder as well as the development of certain external characteristics, can be of decisive significance for the assessment of ecological performance potentials (Fischer et al. 2007).

According to the data given by the Animal Breeding Center Of Thessaloniki (2004), the total populations of indigenous sheep of the greek breed "Serres" numbers only 6647 . That is why they are threatened in disappearing and should be under protection. Their general morphological characteristics are the white uniform fleece, the black bare head and legs with coloured spots and the short neck and belly. Their ears are of medium-size, horizontal or slightly drooping and tassels are often present on the neck.They are fully adapted to the topographic and climatic conditions of local pastures.

For a better management of the sheep flocks and choice of the appropriate production methods, conditions in the breeding environment have to be well-known. Even more important is to know the behavior of animals in such or similar conditions (Bojkovski et al. 2006).

Most of the conducted studies on grazing animals and their behavioral aspects were correlated with climate (Strittmatter 2001, Bojkovski et al. 2006, Chrupek et al. 2006, Fischer et al. 2008) and time spend for activities such as grazing time (Arnold \& Dudzinski 1978), 
distance travel (Warren \& Mysterud 1991, Fischer et al. 2008), resting time (Hinch et al. 1992, Bojkovski et al. 2006) and rumination time (Arnold 1960, Ashutosh Dhanda \& Singh 2002).

The objective of this study was to investigate the grazing activities of indigenous sheep of the greek breed "Serres" in a typical lowland and in a mountainous pasture in northern Greece during a 7-month grazing period.

\section{Material and methods}

Study area

The present study was carried out during the year of 2008 in a typical lowland and in a mountainous pasture of the Prefecture of Serres, northern Greece (Picture). The pasture in the lowlands elevated $55 \mathrm{~m}$ above sea level ( $4057.515 \mathrm{~N}-2324.234 \mathrm{E})$ while the mountainous pasture elevated $800 \mathrm{~m}$ a.s.l. (41 $11.987 \mathrm{~N}-2334.612 \mathrm{E}$ ). The climate of the whole area is Mediterranean. According to the meteorological station of Serres, the total regional annual rainfall was $448.5 \mathrm{~mm}$ while the mean annual temperature was $15.1^{\circ} \mathrm{C}$ (HNMS 2009). The lowland pasture is crossed by a small tributary of Strimon River, a big river coming from Bulgaria. This pasture was composed of annual Graminae (Lolium multiflorum Lam., Bromus tectorum L., Dactylis glomerata L., Holcus lanatus L., Melica ciliata L., Echinochloa crus-galli (L.) Beauv., Paspalum paspaloides (Mischx) Scribner, Stelaria glauca (L.) P.B. and Leguminosae (Medicago litoralis Rhode, Trifolium lappaceum L., Trifolium repens L.) and to a smaller extent of Cruciferae (Arabis glabra (L.) Bernh., Berteroa incana (L.) D.C., Bunias erucago L.), Compositae (Achillea coartata Poiret, Anthemis tinctoria L., Bellis perennis L., Cisrcium arvense (L.) Scop., Carlina corymbosa L.) and shrubs (Quercus coccifera L, Quercus pubescens Wild.). In the mountainous area the pasture was composed mainly of perennial grasses (Avena pratensis L., Briza media L., and Bromus squarrosus L.) and legumes (Lathyrus pratensis L., Lotus tenuis Wald. \& Kit., Trifolium arvense L., Trifolium alpestre L.) and shrubs or small trees (Juniperus communis L., Quercus frainetto Ten). The above mentioned botanical families were nearly always distributed in very complex mixes.

\section{Sampling and experimental analysis}

The greek sheep breed "Serres" is kept in the plain of Serrai (the ancient Seris or Serres) in the Strimon valley of Greek Macedonia. The animals graze in the natural pastures of the area round the villages, without practicing transhumance. They belong to a milk purpose breed with a total milk yield between 124 and $152 \mathrm{~kg}$ in 288 days, and an exploitable yield between 77 and $91 \mathrm{~kg}$ in 228 days.

Two flocks of 265 and 305 sheep were used for a 7 month grazing experiment (from April to October) in the lowland and in the mountainous pasture, respectively. 6 two-year-old female sheep were selected in each flock as experimental animals and were marked with large numbers on their sides for identification purposes. Grazing activities of sheep were recorded 3 times during each experimental month (every 10 days) by 2 trained observers equipped with hand chronometers and mini DV video cameras. Observations were made from $09.30^{\prime}$ to $18.30^{\prime}$ due to the normal practice of the farmers to pen their animals during the night hours. Grazing activities were recorded in min as follows: grazing time (grazing 
or browsing while walking or standing), ruminating (time spent for rumination) and resting time (simply sitting for rest). Distance travel (m) was recorded by a Garmin e-Trex Vista GPS. Air temperature $\left({ }^{\circ} \mathrm{C}\right.$ ) was measured twice per day (early in the morning and at noon) by using an electronic thermometer. These measurements were compared with those given for the year 2008 by HNMS (2009).

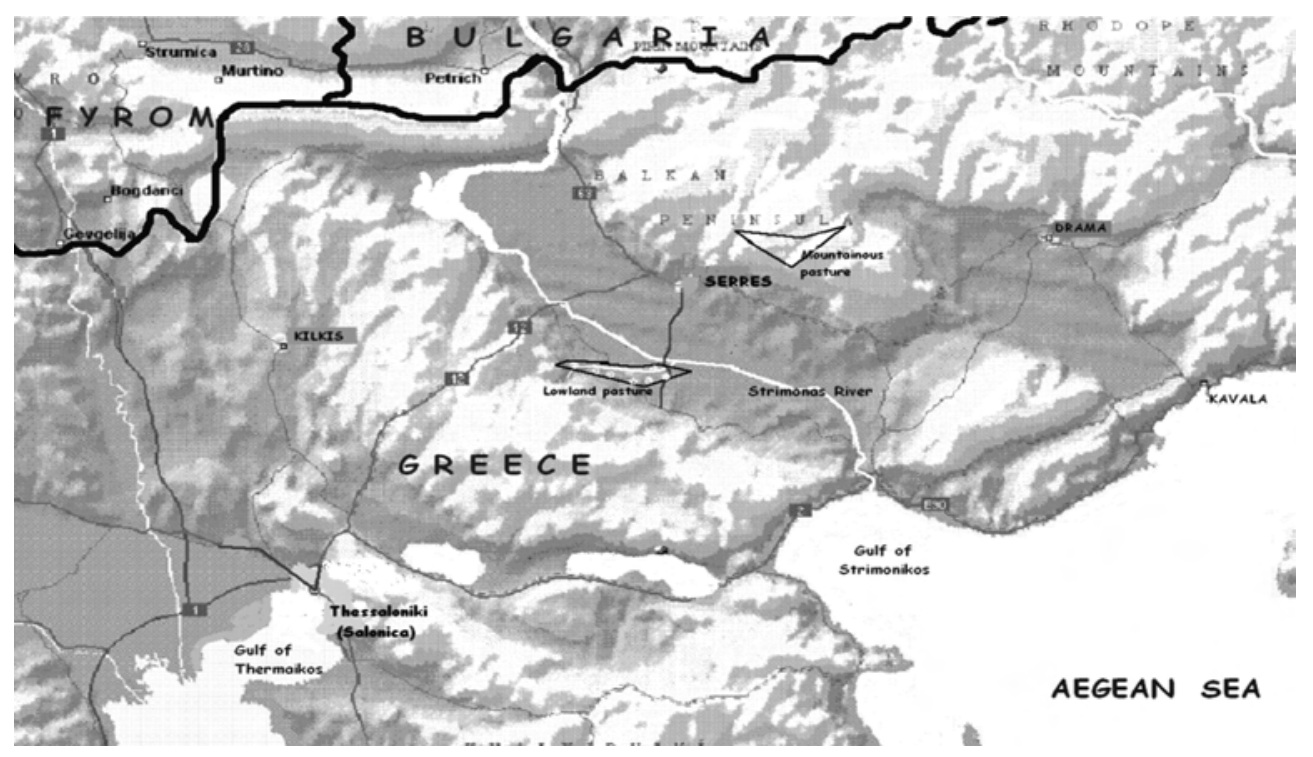

Study area showing sampling pastures

Grazing and resting time, distance travel and air temperature were defined as a mean of the three measurements in each month. The results were calculated with LSM analysis in SPSS 12.0 software for Windows (Kitikidou 2005), due to the following model:

$$
y_{i j k}=\mu+a_{i}+b_{j}+a b_{i j}+e_{i j k}
$$

where $y_{i j k}$ is the of trait value, $\mu$ is the overall mean, $a_{i}$ is the constant effect of the altitude ( $i=1$, $2), b_{j}$ is the constant effect of the month $(j=1,2, \ldots, 7), a b_{i j}$ is the constant effect of $i$-altitude with $\mathrm{j}$-month and $e_{i j k}$ is the random residual effect

Behavioral variables for each month and altitudinal zone were subjected to analysis of variance for repeated measures. Mean separations between adjacent months were obtained with Fisher's Protected LSD test, (Fisher 1966) with statistical significance accepted at $P<0.05$. All » $\Perp$ « symbols in the text refer to standard error of mean (SEM). 


\section{Results and discussion}

\section{Temperature}

The variation in air temperature among subsequent months in the lowland as well as in the mountainous pasture is given in Table 1. The higher temperature was found in mid summer (approximately $30^{\circ} \mathrm{C}$ and $29^{\circ} \mathrm{C}$ in the lowland and in the mountainous area, respectively). However it was found equal differentiation in both grazing areas. Temperature was significantly affected $(P<0.001)$ by both pasturing month and altitude as well as $(P<0.05)$ by the interaction of those factors (Table 2). Air temperature is the most important environmental factor that affects herbage production of pastures and therefore the grazing behavior of sheep (Groberek et al. 2004, Fischer et al. 2008). Forbes (1978) and Zygogiannis (1999) supposed that the beginning and the end of grazing activity depends on air temperature. In addition Blackschaw (1986) reported that temperature affects the total grazing time of sheep. During the hot days sheep grazing was occurred early in the morning and evening and more than usual at night. In a recent study of Evangelou et al. (2010) it was found that sheep during the hot hours of summer ceased all their activities and stood inactive for $320 \mathrm{~min} /$ day.

\section{Grazing Time}

Mean grazing time in the lowland pasture was $315.71 \pm 4.57 \mathrm{~min} /$ day, while in the mountainous pasture was $283.57 \pm 4.79 \mathrm{~min} /$ day (Table 1). Grazing time was significantly higher during spring (April-May) than in the mid-summer months, where higher temperatures observed, in both pastures (Table 1). Generally, sheep spend for grazing the $30-40 \%$ of the 24 -hour (Arnold \& Dudzinski, 1978). Lynch et al. (1992) have reported that the mean grazing time of sheep ranges between 480 and 540 min/day, while Tribe (1955) and Hafez \& Bouissou (1975) have found that the total grazing of sheep ranges between $270-870$ minutes per day. On the contrary, Bojkovski et al. (2006) reported that, on the hilly karst region (900-1000 m a.s.l.) in Slovenia, grazing time of sheep was on the average $10.5 \mathrm{~h}$ per day. The present findings were much lower than those of other researchers because the total grazing time per day was limited. However, they are in agreement with Shinde et al. (1997, cited by Ashutosh Dhanda and Singh 2002) that ruminants tend to avoid grazing during the hot hours of the day and thus reducing their daily grazing time.

Statistical analysis (Table 2) showed that the pasturing month and the altitude significantly effected the duration of grazing $(P<0.01)$. It was also found a significant negative relation $(r=-0.609)$ between grazing time and altitude (Table 3). As shown in Figure 1, grazing time was longer in the lowland and shorter in the mountainous pasture. 

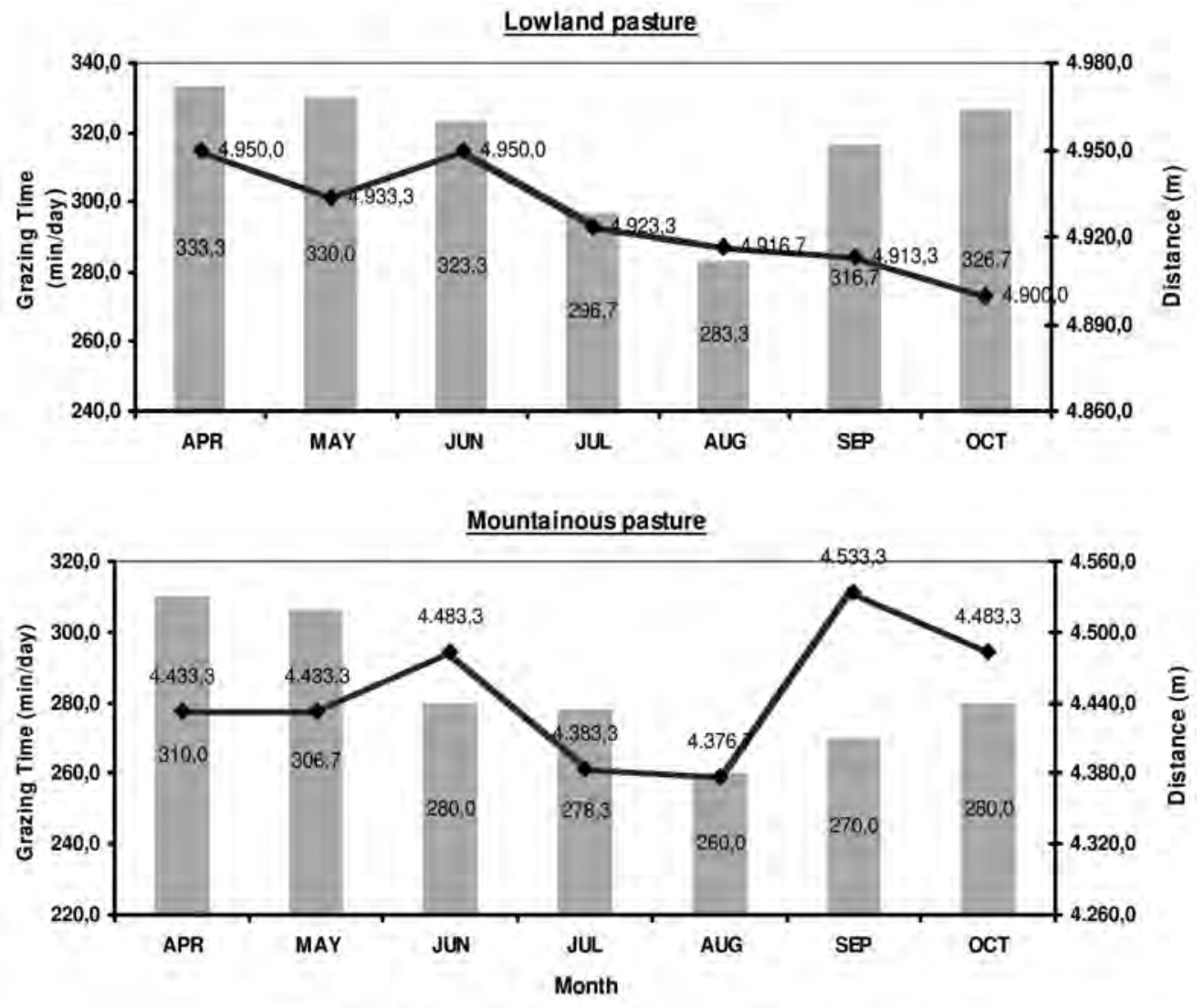

Grazing time (min/day)

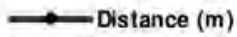

Figure 1

Monthly variation of grazing time of sheep and distance travel

\section{Distance travel}

Mean daily distance travel of sheep was $4926.67 \pm 7.12 \mathrm{~m}$ and $4446.67 \pm 13.77 \mathrm{~m}$ in the lowland and in the mountainous pasture, respectively (Table 1). However, in the lowland pasture, there was not significant variation among the subsequent months (Figure 1). On the contrary, in the mountainous pasture the distance travel of sheep during June and September was significantly different from the rest months. As it was shown in Table 1, the shorter distance travel of sheep in the lowland pasture was found in October $(4900.00 \pm 0.00 \mathrm{~m} /$ day $)$, while the longer it was found in April $(4950.00 \pm 28.87 \mathrm{~m} /$ day). In the mountainous pasture the shortest distance travel was observed in August $(4376.67 \pm 14.53 \mathrm{~m} /$ day) and the longest in September (4533.33 $\pm 16.67 \mathrm{~m} /$ day). Chrupek et al. (2006) was found that the distance travel of polish sheep during June and July averaged $4753.05 \mathrm{~m}$, which is similar to the findings of this study. Askins \& Turner (1972) have reported that the most of the travelling of goats in a west Texas rangeland was observed when the animals grazed and browsed near the water supply, which is in agreement with our findings for the lowland pasture. 
The distance travel of sheep was significantly affected $(P<0.001)$ by the altitude as well as $(P<0.01)$ by the pasturing month and the interaction "altitudexmonth (Table 2). As it is shown in Table 3, there was strong positive relationship between distance and grazing time ( $r=+0.605)$. According to Chrupek et al. (2006) if sheep resided longer on pasture, the distance travel is increased.

Table 1

Effect of vegetation period on grazing behavior parameters in sheep in the lowland and in the mountainous pasture ${ }^{1}$

\begin{tabular}{|c|c|c|c|c|c|}
\hline & $\begin{array}{c}\text { Temperature, } \\
{ }^{\circ} \mathrm{C}\end{array}$ & $\begin{array}{l}\text { Grazing Time, } \\
\text { min/day }\end{array}$ & $\begin{array}{c}\text { Distance travel, } \\
\text { m/day }\end{array}$ & $\begin{array}{c}\text { Resting Time, } \\
\mathrm{min} / \text { day }\end{array}$ & $\begin{array}{c}\text { Ruminating } \mathrm{T} \text {., } \\
\mathrm{min} / \text { day }\end{array}$ \\
\hline \multicolumn{6}{|c|}{ Lowland pasture (55m a.s.l.) } \\
\hline APR & $19.2 \pm 0.2^{d}$ & $333.3 \pm 3.3^{\mathrm{a}}$ & $4950.0 \pm 28.9^{a}$ & $111.7 \pm 4.4^{b}$ & $53.3 \pm 1.7^{a}$ \\
\hline MAY & $23.3 \pm 0.7^{c}$ & $330.0 \pm 2.9^{\mathrm{a}}$ & $4933.3 \pm 33.3^{\mathrm{a}}$ & $115.0 \pm 2.9^{b}$ & $48.3 \pm 1.7^{\mathrm{a}, \mathrm{c}}$ \\
\hline JUN & $25.3 \pm 0.9^{\mathrm{b}, \mathrm{c}}$ & $323.3 \pm 3.3^{\mathrm{a}}$ & $4950.0 \pm .0^{a}$ & $123.3 \pm 3.3^{b, c}$ & $48.3 \pm 1.7^{a}$ \\
\hline JUL & $30.3 \pm 0.9^{a}$ & $296.7 \pm 14.5^{\mathrm{b}, \mathrm{c}}$ & $4923.3 \pm 14.5^{\mathrm{a}}$ & $143.3 \pm 6.7^{\mathrm{a}, \mathrm{c}}$ & $40.0 \pm 0.0^{b}$ \\
\hline AUG & $30.0 \pm 0.6^{\mathrm{a}}$ & $283.3 \pm 8.8^{b}$ & $4916.7 \pm 16.7^{\mathrm{a}}$ & $160.0 \pm 10.0^{\mathrm{a}}$ & $50.0 \pm 0.0^{\mathrm{a}}$ \\
\hline SEPT & $26.7 \pm 0.7^{b}$ & $316.7 \pm 8.8^{\mathrm{a}, \mathrm{c}}$ & $4913.3 \pm 6.7^{\mathrm{a}}$ & $123.3 \pm 13.3^{b, c}$ & $35.0 \pm 5.0^{b}$ \\
\hline OCT & $20.7 \pm 0.9^{d}$ & $326.7 \pm 3.3^{\mathrm{a}}$ & $4900.0 \pm 0.0^{\mathrm{a}}$ & $113.3 \pm 6.7^{b}$ & $43.3 \pm 1.7^{b, c}$ \\
\hline Mean & $25.1 \pm 0.9$ & $315.7 \pm 4.6$ & $4926.7 \pm 7.1$ & $127.1 \pm 4.4$ & $45.5 \pm 1.5$ \\
\hline \multicolumn{6}{|c|}{ Mountainous pasture ( $800 \mathrm{~m}$ a.s.I.) } \\
\hline APR & $18.7 \pm 0.3^{e}$ & $310.00 \pm 5.8^{\mathrm{a}}$ & $4433.3 \pm 33.3^{\mathrm{b}, \mathrm{c}}$ & $120.0 \pm 0.0^{\mathrm{b}, \mathrm{c}}$ & $38.3 \pm 4.4^{c}$ \\
\hline MAY & $20.7 \pm 0.3^{d}$ & $306.7 \pm 3.3^{a, b}$ & $4433.3 \pm 16.7^{b, c}$ & $113.3 \pm 3.3^{b, c}$ & $48.3 \pm 1.7^{b, d}$ \\
\hline JUN & $25.7 \pm 0.3^{b}$ & $280.0 \pm 5.8^{\mathrm{b}, \mathrm{c}}$ & $4483.3 \pm 16.7^{a}$ & $133.3 \pm 8.8^{\mathrm{b}}$ & $60.0 \pm 0.0^{\mathrm{a}}$ \\
\hline JUL & $27.7 \pm 0.3^{\mathrm{a}}$ & $278.3 \pm 9.3^{c}$ & $4383.3 \pm 33.3^{b}$ & $150.0 \pm 0.0^{\mathrm{a}}$ & $53.3 \pm 3.3^{\mathrm{a}, \mathrm{b}}$ \\
\hline AUG & $29.3 \pm 0.3^{a}$ & $260.0 \pm 5.8^{c}$ & $4376.7 \pm 14.5^{b}$ & $170.0 \pm 10.0^{\mathrm{a}}$ & $56.7 \pm 3.3^{\mathrm{a}, \mathrm{b}}$ \\
\hline SEPT & $23.0 \pm 1.0^{c}$ & $270.0 \pm 17.3^{c}$ & $4533.3 \pm 16.7^{a}$ & $130.0 \pm 10.0^{\mathrm{b}}$ & $48.3 \pm 1.7^{b}$ \\
\hline ОСТ & $17.3 \pm 0.9^{\mathrm{e}}$ & $280.0 \pm 10.0^{b, c}$ & $4483.3 \pm 16.7^{\mathrm{a}, \mathrm{c}}$ & $103.3 \pm 6.7^{c}$ & $40.0 \pm 5.0^{c, d}$ \\
\hline Mean & $23.2 \pm 1.0$ & $283.6 \pm 4.8$ & $4446.7 \pm 13.8$ & $131.4 \pm 5.2$ & $49.3 \pm 2.0$ \\
\hline
\end{tabular}

${ }^{1}$ Mean values of 3 sampling days per month \pm standard error of mean (SEM), a,b,c,d,e Means with different superscripts along the same column differ at $P<0.05$

Table 2

Influence of the pasturing month and the altitude of pasture on grazing activities of indigenous sheep of greek breed "Serres"

\begin{tabular}{lccc}
\hline Parameter & Month & Altitude & Month $\times$ Altitude \\
\hline Grazing time, min/day & $* * *$ & $* * *$ & $\mathrm{~ns}$ \\
Resting time, min/day & $* * *$ & $\mathrm{~ns}$ & $\mathrm{~ns}$ \\
Ruminating time, min/day & $* * *$ & $* *$ & $* * *$ \\
Distance travel, $\mathrm{m} /$ day & $* *$ & $* * *$ & $* *$ \\
Air temperature, ${ }^{\circ} \mathrm{C}$ & $* * *$ & $* * *$ & $*$ \\
\hline
\end{tabular}

Level of significance: ${ }^{* *} P<0.001,{ }^{* *} P<0.01,{ }^{*} P<0.05$, ns: not significant 


\section{Lowland pasture}
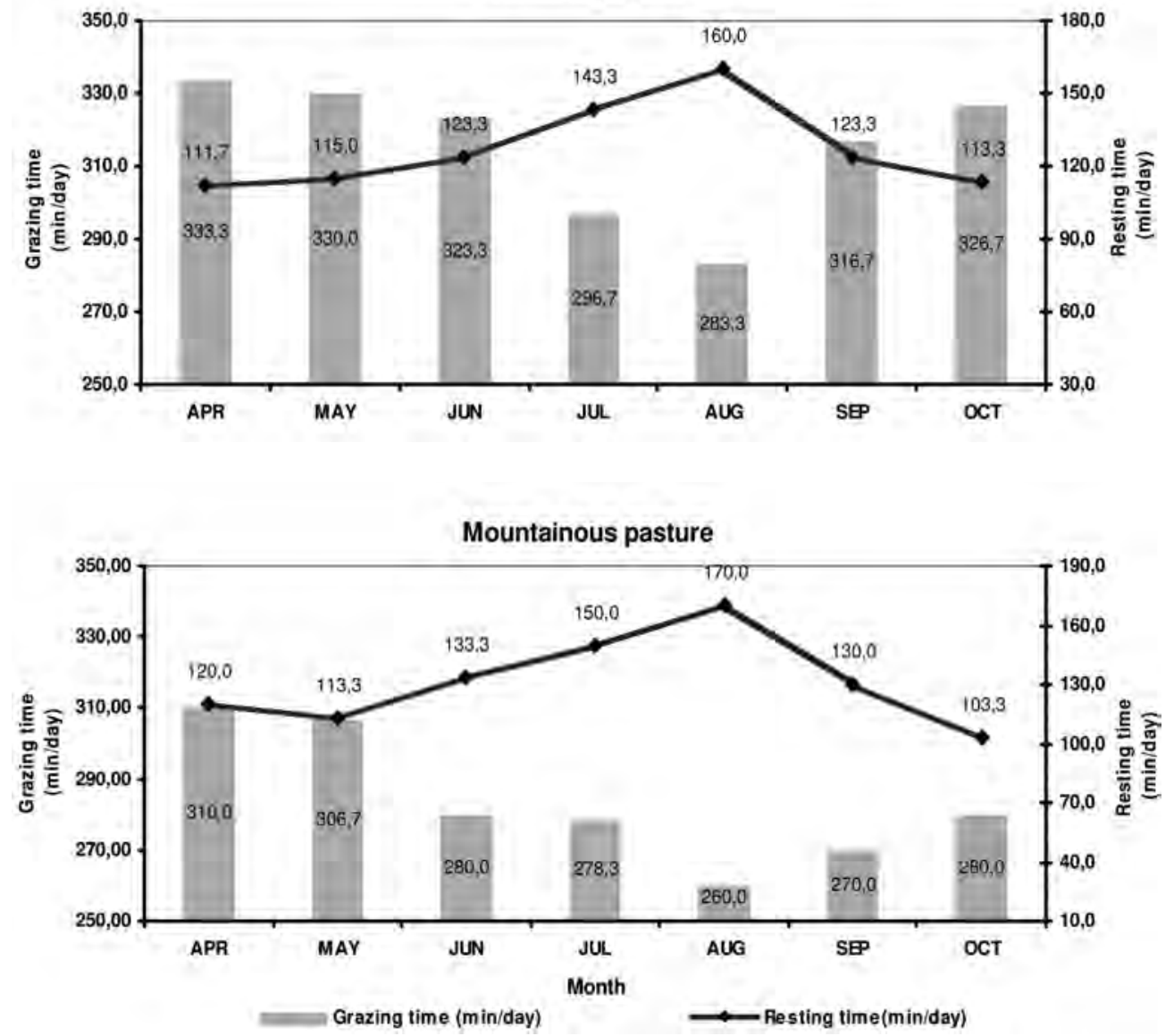

Figure 2

Monthly variation of grazing time and resting time

Table 3

Correlation coefficients between examined parameters

\begin{tabular}{lccccccc}
\hline Parameter & Altitude & Month & $\begin{array}{c}\text { Grazing } \\
\text { time, } \\
\text { min/day }\end{array}$ & $\begin{array}{c}\text { Resting } \\
\text { time, } \\
\text { min/day }\end{array}$ & $\begin{array}{c}\text { Ruminating } \\
\text { time, } \\
\text { min/day }\end{array}$ & $\begin{array}{c}\text { Distance } \\
\text { travel, } \\
\mathrm{m} / \text { day }\end{array}$ & $\begin{array}{c}\text { Air } \\
\text { Temp., } \\
{ }^{\circ} \mathrm{C}\end{array}$ \\
\hline Altitude & 1 & & & & & & \\
Month & 0.000 & 1 & & & & & \\
Grazing time, $\min /$ day & $-0.609^{* *}$ & $-0.365^{*}$ & 1 & & & & \\
Resting time, $\mathrm{min} /$ day & 0.099 & 0.129 & $-0.557^{* *}$ & 1 & & & \\
Ruminating time, $\mathrm{min} /$ day & 0.237 & -0.237 & $-0.383^{*}$ & $0.461^{* *}$ & 1 & & \\
Distance travel, $\mathrm{m} /$ day & $-0.980^{* *}$ & 0.003 & $0.605^{* *}$ & -0.172 & -0.241 & 1 & \\
Air temperature, ${ }^{\circ} \mathrm{C}$ & -0.218 & 0.167 & $-0.377^{*}$ & $0.777^{* *}$ & 0.269 & 0.152 & 1 \\
\hline
\end{tabular}

Level of significance: ${ }^{*} P<0.05,{ }^{*} P<0.01$ 


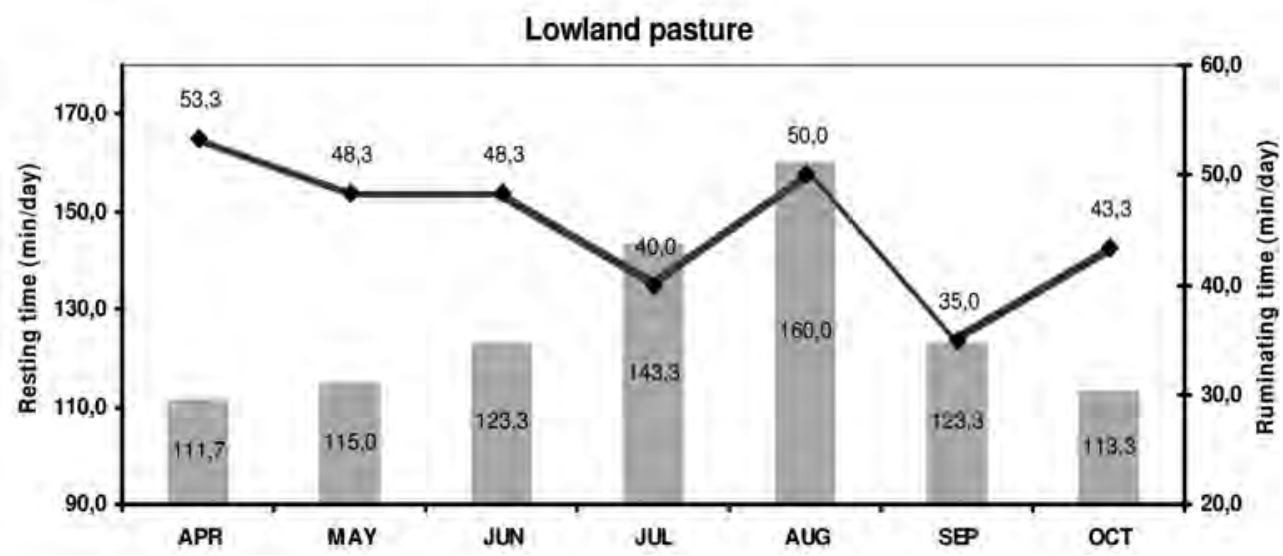

Mountainous pasture

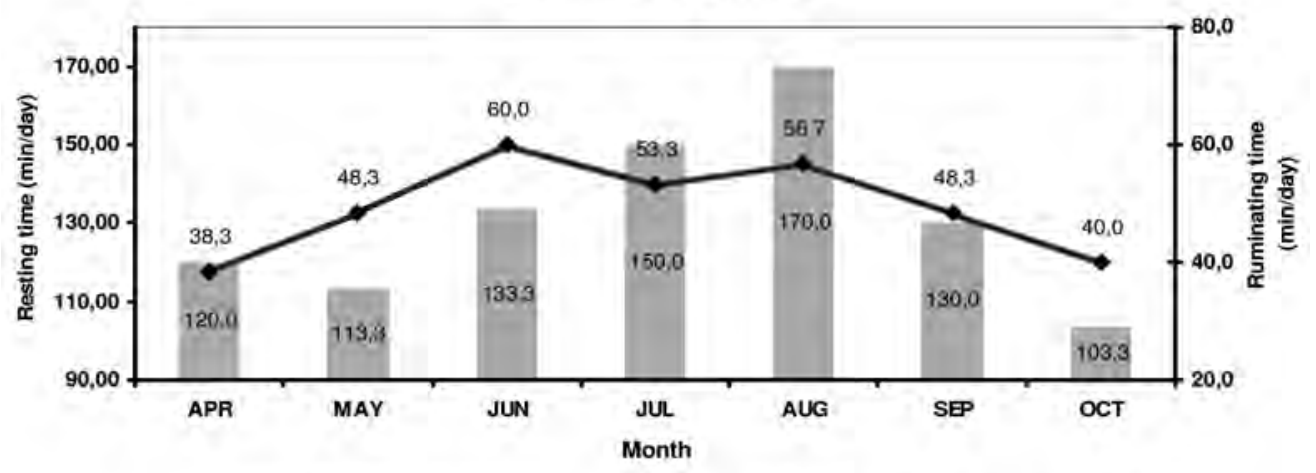

Resting time (min/day)

— Ruminating time (min/day)

Figure 3

Monthly variation of resting time and ruminating time

Ruminating time was different between the two pastures. In the lowland pasture ruminating time was decreased among months (except for August) while in the mountainous one it was increased till June and then decreased till the end of the grazing period (Table 1 and Figure 3). In the lowland pasture the greater value for ruminating time was found in August $(50.00 \pm 0.00 \mathrm{~min} /$ day $)$ while in the mountainous one it was found in June $(60.00 \pm 0.00 \mathrm{~min} /$ day). Ruminating time was significantly affected $(P \leq 0.01)$ by both pasturing month and altitude of the pasture (Table 2). Rumination alternate with grazing and resting time (Squires, 1971) and is related to resting time. In the present study rumination follows as similar variation to resting time (Figure 3 ).

It is concluded that, grazing activities of the indigenous sheep of the greek breed "Serres" were influenced by the environmental conditions and the heterogenous vegetation of the lowland and the mountainous pastures. The animals spent more grazing time and less resting time in the lowland pasture than in the mountainous one. They also had a shorter distance travel per day indicating that maybe this breed is better adapted to the forage conditions of the lowland pasture. 
Further research on the quantity and quality of herbage preferred by sheep and their relation to grazing behavior of sheep will be useful to sheep-breeders to select the appropriate method of management in northern Greeks' pastures.

\section{Lowland pasture}

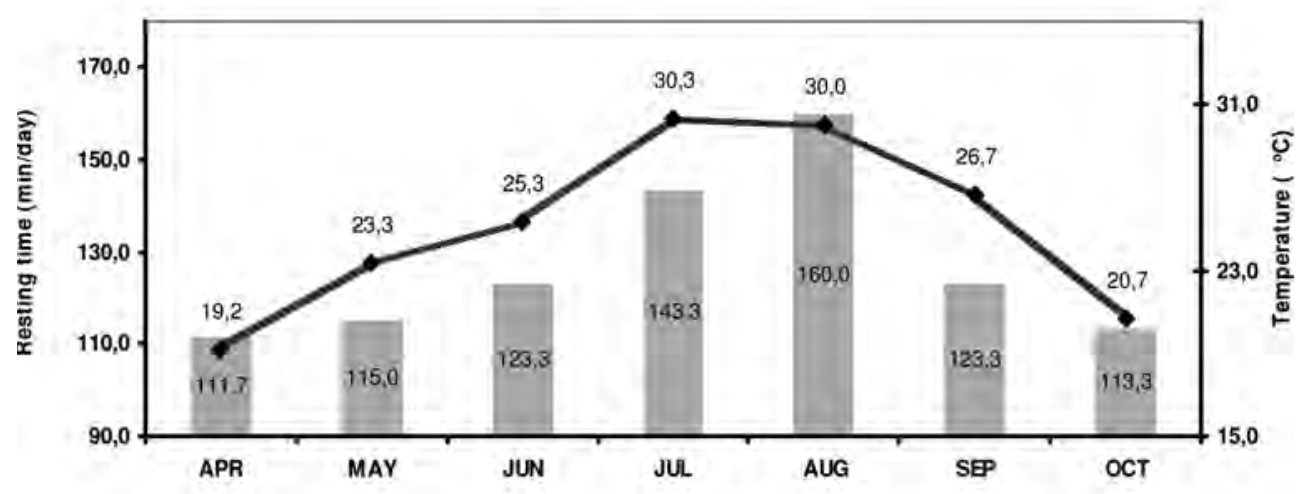

Mountainous pasture

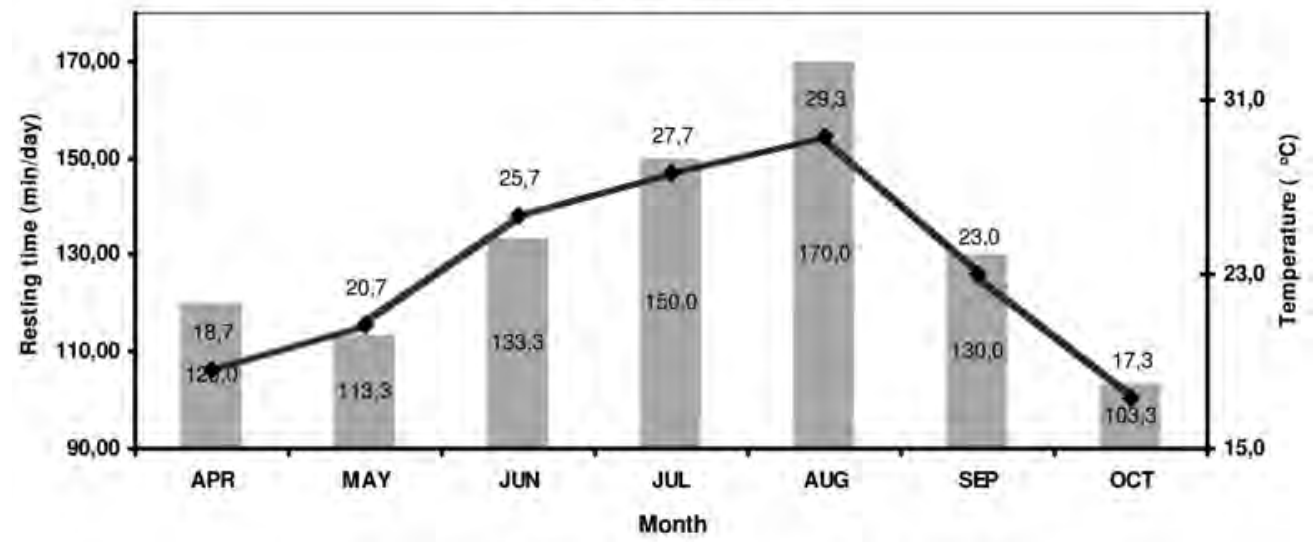

Resting time (min/day)

Figure 4

Monthly variation of resting time and air temperature

\section{References}

Aldezabal A, Garin I, García-González R (1999) Activity rhythms and the influence of some environmental variables on summer ungulate behaviour in Ordesa-Monte Perdido National Park. Pirineos 153, 145-157

Animal Breeding Center of Thessaloniki (2004) Sheep of Greek breed "Serres". Hellenic Ministry of Rural Development and Food. Athens, Greece

Arnold GW (1960) The effect of the quantity and quality of pasture available to sheep on their grazing behavior. Austr. J Agric Res 11, 1026-1033

Arnold GW, Dudzinski ML (1978) Ethology of Free-ranging Domestic Animals. Developments in Animal \& Veterinary Sciences 2, Elsevier, Amsterdam, The Netherlands 
Ashutosh Dhanda OP, Singh G (2002) Changes in grazing behavior of native and crossbred sheep in different seasons under semi-arid conditions. Trop Anim Health Prod 34, 399-404

Askins GD, Turner EE (1972) A Behavioral Study of Angora Goats on West Texas Range. J Range Manage 25, 82-87

Blackschaw JK, (1986) Notes on some topics in applied animal behavior. School of Veterinary Science, Australia, 100

Bojkovski D, Stuhec I, Kompan D (2006) Behaviour of sheep in three different types of paddock in karst region of Slovenia. Acta Agraria Kaposváriensis, 10, 159-167

Brüne $\mathrm{CH}$, Stumpf T (2004) Grazing of heath and poor sands pasture with sheep and goats. Arch Tierz 47 Special Issue, 18-24 [in German]

Chrupek D, Groberek J, Niżnikowski R, Brzostowski H, Strzelec E, Popielarczyk D, Marciniec M (2006) Characteristic of Polish heath sheep grazing behaviour on fallow lands during vegetative period, concerning pasturage time and weather conditions. Arch Tierz 49 Special Issue, 353-358

Evangelou CH, Yiakoulaki MD, Papanastasis VP (2010) Seasonal changes in grazing activities of sheep and goats in communal mediterranean rangelands of northern Greece. Proceedings of the 7th National Conference on Rangelands (Range Science and Life Quality). Xanthi Greece, 249-253 [in Greek with English summary]

Fischer A, Schalitz G, Behrendt C (2007) Breed-specific classification potentials of sheep in different grassland biotopes Arch Tierz 50, 174-185

Fischer A, Schalitz G, Behrendt A (2008) Comparative studies on the grazing behavior of fallow deer and sheep in winter. Arch Tierz 51, 487-497

Fisher RA (1966). The design of experiments. 8th ed. Hafner, New York, USA

Forbes JM (1978) Models of the control of food intake and energy balance in ruminants. Appl Anim Behavior Sci 32, 167-177

Groberek J, Niżnikowski R, Pfeffer E, Rawa J, Marciniec M (2004) The estimation of nutritive value of pasture grass on wasteland used in sheep production. Arch Tierz 47 Special Issue, 153-159

Hafez ESE, Bouissou MF (1975) The behaviour of cattle. In: Hafez ESE (ed) The behaviour of domestic animals. 3rd ed. Baillière Tindall, London, UK, 203-245

Hinch GN, Lynch JJ, Adams DB (1992) Grazing behavior in sheep. In: Lynch JJ, Hinch GN, Adams DB (auth) The behaviour of sheep, biological principles and implications for production. CAB International, Wallingford, UK, 9-47

H.N.M.S: (2009) Hellenic National Meteorological Service. Athens, Greece

Kemp DR, King WM, Gilmour AR, Lodge GM, Murphy SR, Quigley PE, Sanford P, Andrew MH (2003). SGS Biodiversity Theme: Impact of plant biodiversity on the productivity and stability of grazing systems across southern Australia. Aust J Exp Agric 43, 961-975

Kitikidou K (2005) Applied statistics using SPSS. Tziolas Press Thessaloniki, Greece, 288

Lynch JJ, Hinch GN, Adams DB (1992) The behaviour of sheep, biological principles and implications for production. CAB International, Wallingford, UK

Sarlis GP (1998) Range Management. Part 1. A. Stamoulis Press, Athens, Greece, 341

Shinde AK, Karim SA, Patnayak BC, Mann JS (1997) Dietary preferences and grazing behavior if sheep on Cenchrus ciliaris pasture in semi arid region of India. Small Rumin Res 26, 119-122

Spiegelberger MD, Müller-Schärer H, Schaffner U (2006) Scale-dependent effects of land use on plant species richness of mountain grassland in the European Alps. Ecography, 29, 541-548

Squires V (1971) Temporal patterns of activity in a small flock of Merino sheep as a determined by an automatic recording technique. Anim Behavior 19, 657-660

Squires VR (1975) Social behaviour in domestic livestock: the basis for improved animal husbandry. Appl Anim Ethol, 177-184

Strittmatter K (2001) The behaviour of sheep of different breeds on pastures recultivated after mining. Arch Tierz 44 Special Issue, 224-229 [in German] 
Tribe DE (1955) The behavior of grazing animals. In: Hammond J (ed) Physiology of Farm Animals, Vol. 2. Butterworths, London, UK, 285

Warren JT, Mysterud I (1991) Summer habitat use and activity patterns of domestic sheep on coniferous forest range in southern Norway. J Range Manage 44, 2-6

Zervas G, Fegeros K, Papadopoulos G, (1996) Feeding system of sheep in a mountainous area of Greece. Small Rumin Res 21, 11-17

Zygogiannis DG (1999) Sheep Farming: Ruminant animal farming. Synchroni Paedia Press. Thessaloniki Greece, 431

Yiakoulaki MD, Zarovali MP, Ispikoudis I, Papanastasis VP (2003) Evaluation of small ruminant production systems in the area of Lagadas County. Proceedings of the 3rd National Conference on Rangelands (Range Science and Development of Mountainous Areas). Karpenisi, Greece, 395-402 [in Greek with English summary]

Received 7 January 2010, accepted 15 January 2011.

Corresponding author:

loannis Mountousis

email:dkklinon@otenet.gr or mountousisioa@cyta.gr

Department of Animal Production, Faculty of Agriculture, Technological Educational Institute of Western Macedonia, Terma Kontopoulou, 53100 Florina, Greece. Home address: Kapetan Zoi 2, 53100 Florina, Greece 